\title{
STUDENTS' ACCEPTANCE TOWARDS KAHOOT APPLICATION IN MASTERING CULINARY TERMINOLOGY
}

\author{
Adibah Aishah Md Sahak, ", Abdul Wafi Abdul Rahman², Mohd Raden Farhan Helmy Raden \\ Ismail $^{3}$, Mohd Akmal Rohiat ${ }^{4}$, Nur Diyana Mohd Yazid ${ }^{5}$, Siti Nurshafiqa Aminudin 6 , \\ Siti Hajar Zakariah ${ }^{7}$ \\ 1, 2, 3, 4, 5, 7 Department of Vocational Education (Catering), Faculty of Technical and Vocational Education, Universiti Tun \\ Hussein Onn Malaysia, 86400 Parit Raja, Batu Pahat, Johor, Malaysia \\ ${ }^{6}$ Universiti Tun Hussein Onn Malaysia, 86400 Parit Raja, Batu Pahat, Johor, Malaysia \\ E-mail: adibah@uthm.edu.my* \\ *Corresponding Author
}

\begin{abstract}
Kahoot! is a game-based learning platform used to review students' knowledge, for formative assessment and provides an opportunity not only to assess students' conceptual understanding but also to build new knowledge through further clarification during or after the game. The objective of this study is to assess the acceptability of culinary students in the use of Kahoot! application for mastery the culinary terminology. This study aimed to identify students' acceptance of learning applications, to identify students' acceptance of Kahoot! use in terms of memory as well as students' level of mastering Kahoot! in the learning process. This study is a descriptive study that used a five-point Likert scale questionnaire as an instrument. A total of 48 second year students from the Catering program were used as the study sample. The collected data were analyzed using Statistical Package for Social Science Version 23.0 for Windows (SPSS). The results show that the aspect of students' level of mastering the culinary terminology using Kahoot! application is high with a mean score of 4.55. Whereas the students' acceptance of Kahoot! as a learning application, was also high with a mean score of 4.44 . Finally, the students' acceptance of the culinary terminology tested using Kahoot! is high with a mean score of 4.45 .
\end{abstract}

Keywords: acceptability, application of Kahoot!, student memory power

\section{INTRODUCTION}

Rapid advances in global and local information and communications technology (ICT) have brought a stream of changes to a more informed and active way of interacting on social media through the medium of the internet. Technology helps people to improve their teaching and learning methods. In the education field also no exception to accepting the impact and positive benefits of the results from the explosion of this information and communication technology. The process of teaching and learning can also be further enhanced and diversified in terms of delivery and acceptance through techniques such as computer and software, network systems, software, and databases or internet systems. The use of this method of teaching is said to increase interest and stimulate the minds of students in this cyber age. Kahoot! also provides an opportunity not only to assess students' conceptual understanding but also to build new knowledge through further clarification during or after the game.

Game-based learning is a technique that helps students increase the potential and quality. This is in line with a statement issued by Dellos [1] which states that game-based learning is a powerful tool for enabling students to learn to solve problems, build critical thinking, and enable assessment. Kahoot! is a tool of innovation in upgrading the teaching and learning method to students. Game-based learning can be considered as a teaching method that allows students to explore different parts of the game as a form of learning to help them improve their skills or achieve specific learning outcomes. Game-based learning is a studentcentered learning approach that uses digital games to support educational goals in teaching and learning. 
The second-year students or novice students are less experienced students in the domain with less existing knowledge, often lacking in experience and effective schemas to solve problems. Teaching that consists of problem-solving elements is believed to be ineffective because novice students are constantly trying to solve problems using weak strategies, such as finite-intent strategies that involve interaction with large amounts of information that lead to high extraneous cognitive load. Because extraneous cognitive load can affect learning, it should be avoided during the learning process [2].

In addition, Kapp [3] states that to be successful in a game-based education, requires relevant context, proper cognitive activity, meaningful challenges, and feedback. Rieber [4], points out that there are four features of the game that are voluntary, involve instructional innovation and do not rely on external rewards, involve some active stages of physical activity, and their involvement with other activities in terms of the quality of their pretensions.

This blended learning concept is mixing conventional learning patterns with online learning. Therefore, the application of blended learning should be implemented and applied in line with the current development of information and communication technologies. Hussin et al. [5] propose that there are three important learning methods which are (1) lecture, (2) classroom practice, and (3) using the Kahoot! game-based student response system. These studies have shown that Kahoot! can be used as a pedagogical tool to improve students' learning performance. Game-based learning also involves a wide range of emotions, from curiosity, confusion, frustration to happiness when completing the game successfully. The game-based learning approach also enables students to constantly seek knowledge to satisfy their curiosity and to achieve self-fulfillment.

There are many benefits to be gained based on game-based learning that can help to improve the effectiveness of the learning process for students at all academic levels [6]-
[10]. In particular, this game-based learning is intended to enable students to experience and overcome intellectual education challenges [11]

Memory is measured using the explicit method (involving the explicit memory measure (visible) and the implicit method). The exploratory method has two memory measures namely recall and recognition. Recall requires that a person retrieve knowledge stored in longterm memory. Storage of memory information consists of sensory memory storage, short-term memory, and working memory (Long term memory).

Through the observations, researchers have found that the second-year culinary students are particularly hard to remember terms of culinary fields that are mostly of French origin although they often use them during the teaching and learning process such as terms of ala-carte and trussing process. In addition, they do not understand the meaning behind the terms they use and cannot properly pronounce the term because they are not well exposed to it.

Various studies have shown that the use of Kahoot! can make the classroom energized, students feel comfortable and can motivate students to learn a topic [12]-[17]. The present study provides several benefits of Kahoot! in teaching and learning which is very easy to use, works on any devices such as computers and mobile phones with the internet, therefore players do not have to sign up for accounts, the players can play and connect with other players in other countries, besides promoting social learning and Kahoot! free services. As such, it helps the effectiveness of audio and visual usage in Kahoot! learning environments includes students' focus, engagement, fun, and motivation [18]. The main objective of this paper is to find students' acceptance of learning applications. Even though many researchers were reported acceptance toward teaching and learning online, very few researchers were reported about the tool for mastering the terminology in culinary by using Kahoot!. A previous pilot study from Taylor \& Reynolds 
[19] in South Korea with 51 university students found that Kahoot! improves vocabulary retention while exposing a positive learning environment and a meaningful learning experience towards students. Its mention by Hadijah et al. [20], Kahoot! is good at improving the students' vocabulary skills and motivate students to prepare themselves in facing the test by learning the materials given by the lecturer. The data in this is useful in variation techniques teaching and learning for lecturers.

A few researchers focused on effective teaching and learning in the online platform but there have been limited studies concern platforms for application tools for the memory power of students. Therefore, this study intends to acknowledge lecturer the benefit of Kahoot! toward mastering terminology and the form of personal training, reviews, and online assignments that shown students are more motivated and excited to learn a topic. The objectives of this study are to identify the students' acceptance of Kahoot! as a learning application and to identify students' acceptance of Kahoot! uses in terms of memory as well as students' level of mastering Kahoot! in the learning process.

\section{METHOD}

This study was conducted at University Tun Hussein Onn Malaysia. A total of 55 culinary students was taking part in this study. Krejcie \& Morgan [21] stated that determining a sample size of 48 students with a total population of 56 students is sufficient to collect the data. The instrumentation of this study used a five-point Likert scale. Other than that, the scale in the Likert scale value of 1 refers to (strongly disagree), 2 (disagree), 3 (neutral), 4 (agree), and 5 (strongly agree) which is the most strongly attitude in the scale. The data was then coded and analyzed using the Statistical Package of Social Science (SPSS). The respondents were asked to answer a few questions regarding the Kahoot! application before answered the questionnaire regarding this research. The question was based on the basic terminology in the culinary field which is the students already learned about it.

\section{RESULTS AND DISCUSSION}

This section discussed the research objectives and research questions. The research objectives are: (1) to know the students' acceptance of Kahoot! as a learning application, (2) to identify the acceptance of students from the power aspects of remembering the term culinary in the use of Kahoot! during the learning process, and (3) to identify the level of students' mastering in term of culinary terminology by using Kahoot! during the learning process.

The first research objective is to know the students' acceptance of Kahoot! as a learning application. The results of the respondents 'responses regarding students' acceptance of the use of Kahoot! as a learning application are presented in Table 1. As previously mentioned, these studies were conducted to know the acceptance of Kahoot! as a learning application. Based on Table 1, the highest mean score is 4.73 and the lowest mean score is 4.13 . This showed that the students are happy when they get the correct answer during the activity using the Kahoot! application. Hence, the students accepted Kahoot! as the learning application. Whereas, for the lowest mean score, when the students unable or wrongly answered the questions through the games, they will try back the game by completing the revision to get the highest marks. This shows that students' acceptance of Kahoot! as a learning application is high because the games increased their enthusiasm and excitement towards the learning process. This result supports Bicen \& Kocakoyun [22] who reported that Kahoot! application has a positive impact on students' interest, ambitions, and motivation in the class.

The second research objective identifies the acceptance of students from the power aspects of remembering the term culinary in the 
use of Kahoot! during the learning process. The following are the results of the respondents 'feedback on the students' perception of culinary terms in the use of Kahoot! during the learning process. Table 2 shows the mean scores of power aspects of remembering the culinary term using Kahoot! application during the learning process. The results present the three highest mean scores were 4.58, 4.54, and 4.44.

Table 1. Mean Scores of Students' Acceptance of Kahoot!

\begin{tabular}{|c|c|c|c|}
\hline No & Item & Mean & $\begin{array}{c}\text { Tendency } \\
\text { Level }\end{array}$ \\
\hline 1 & $\begin{array}{l}\text { I feel the use of Kahoot! } \\
\text { in my lessons can improve } \\
\text { my learning experience. }\end{array}$ & 4.52 & High \\
\hline 2 & $\begin{array}{l}\text { I found that the use of } \\
\text { Kahoot! in learning is } \\
\text { very effective. }\end{array}$ & 4.35 & High \\
\hline 3 & $\begin{array}{l}\text { I feel fun when it is able } \\
\text { to provide the right } \\
\text { answer during the activity } \\
\text { of Kahoot!. }\end{array}$ & 4.73 & High \\
\hline 4 & $\begin{array}{l}\text { Kahoot!'s activity } \\
\text { contributed to the } \\
\text { improvement of my } \\
\text { memory in the culinary } \\
\text { field term. }\end{array}$ & 4.52 & High \\
\hline 5 & $\begin{array}{l}\text { I am actively involved in } \\
\text { learning if the Kahoot! } \\
\text { activity is implemented }\end{array}$ & 4.46 & High \\
\hline 6 & $\begin{array}{l}\text { Learning through Kahoot! } \\
\text { has made my interest in } \\
\text { learning higher. }\end{array}$ & 4.48 & High \\
\hline 7 & $\begin{array}{l}\text { I'm going to revision the } \\
\text { subjects to get the highest } \\
\text { score in the Kahoot! } \\
\text { activity among my class } \\
\text { partners. }\end{array}$ & 4.13 & High \\
\hline 8 & $\begin{array}{l}\text { I communicate more with } \\
\text { my friends to become } \\
\text { more competitive through } \\
\text { the Kahoot! method. }\end{array}$ & 4.30 & High \\
\hline 9 & $\begin{array}{l}\text { Winning a good position } \\
\text { through the Kahoot! game } \\
\text { method makes me feel } \\
\text { appreciated }\end{array}$ & 4.38 & High \\
\hline 10 & $\begin{array}{l}\text { I want this game activity } \\
\text { to be used in other lessons } \\
\text { as well }\end{array}$ & 4.52 & High \\
\hline
\end{tabular}

The results show that Kahoot! improves the cognitive level of the students as the Kahoot! application allowed students to remember the lessons, stimulates the interest in learning, and improves the thinking ability. Whereas the lowest mean was 4.29 which by using the Kahoot! application, students can improve their performance and learning process. This result ties well with previous studies wherein Yürük [23] and Baszuk \& Heath [24] conclude that Kahoot! application encourages students' engagement and allows students to make connections between course topics and learning pathways while alerting teachers to learning gaps.

Table 2. Mean Scores of Students' Acceptance from the Power Aspects of Remembering the Culinary Term Using Kahoot! Application during the Learning Process

\begin{tabular}{|c|c|c|c|}
\hline No & Item & Mean & $\begin{array}{c}\text { Tendency } \\
\text { Level }\end{array}$ \\
\hline 1 & $\begin{array}{l}\text { Kahoot! improves my } \\
\text { thinking ability }\end{array}$ & 4.44 & High \\
\hline 2 & $\begin{array}{l}\text { Using pictures in Kahoot! } \\
\text { allows me to easily } \\
\text { remember the content of } \\
\text { the lesson }\end{array}$ & 4.58 & High \\
\hline 3 & $\begin{array}{l}\text { Using Kahoot! can } \\
\text { improve my performance } \\
\text { and my learning progress. }\end{array}$ & 4.29 & High \\
\hline 4 & $\begin{array}{l}\text { My memory improves } \\
\text { when I learn to use } \\
\text { Kahoot!. }\end{array}$ & 4.40 & High \\
\hline 5 & $\begin{array}{l}\text { The use of Kahoot! can } \\
\text { stimulate my interest in } \\
\text { learning }\end{array}$ & 4.54 & High \\
\hline
\end{tabular}

The third research objective is to identify the level of mastery of the students in the term of the culinary in the use of Kahoot! during the learning process. The results of the respondents' feedback on the level of students mastering the culinary terminology using Kahoot! application during the learning process are shown in Table 3. The highest mean score for the third objective is 4.60 while the lowest mean score is 4.52. Overall, the results show that students' encouragement in the learning process is high when used the latest technology-based materials. The students also agreed that Kahoot! makes the learning process more effective, easier for the students to understand, and helps to strengthen the term understanding in the field of culinary. A similar result was obtained in Medina \& Hurtado [25] who provide evidence that the use of Kahoot! improved acquisition of vocabulary and the students enjoyed playing Kahoot! and found it easy to use. 
Table 3. The Level of Student's Mastering in Terms of Culinary Terminology by Using Kahoot! Application during the Learning Process

\begin{tabular}{|c|c|c|c|}
\hline No & Item & Mean & $\begin{array}{c}\text { Tendency } \\
\text { level }\end{array}$ \\
\hline 1 & $\begin{array}{l}\text { The use of Kahoot! } \\
\text { encourages students to use } \\
\text { the latest technology-based } \\
\text { materials in their learning } \\
\text { process. }\end{array}$ & 4.60 & High \\
\hline 2 & $\begin{array}{l}\text { Using Kahoot! makes } \\
\text { collaborative learning more } \\
\text { effective. }\end{array}$ & 4.52 & High \\
\hline 3 & $\begin{array}{l}\text { Activities made using } \\
\text { Kahoot! are more attractive } \\
\text { and easier to master }\end{array}$ & 4.56 & High \\
\hline 4 & $\begin{array}{l}\text { The content of the lessons } \\
\text { implemented in this } \\
\text { Kahoot! game makes it } \\
\text { easy for students to } \\
\text { understand the essence of } \\
\text { the lesson. }\end{array}$ & 4.52 & High \\
\hline 5 & $\begin{array}{l}\text { Kahoot! helps strengthen } \\
\text { the term in the field of } \\
\text { culinary. }\end{array}$ & 4.52 & High \\
\hline
\end{tabular}

\section{CONCLUSION}

From this study, it was revealed that the students can accept the use of Kahoot! as a teaching and learning tool in the culinary field, especially in theory classes. The findings also showed that Kahoot! can be used before the lecturers ended the class for the students to review what they have learned in the class on that day. Kahoot! also was very suitable as game-based learning method, which provide a positive impact for students, faculty, and university. For the recommendation, researchers suggest that lecturers integrate student-centered and material-centered approaches when applying game-based learning in the classroom. Lecturers also need to change their teaching style from conventional teaching to interactive learning that is aided by today's technology. Next, for the future researcher, they can also conduct this study for students from different fields at UTHM so that their findings can be used in the future. The researcher also may use other instruments such as interview methods or by observing the students involved in the study to obtain more accurate data. Other than that, researchers are also encouraged in future research to consider large samples that involve other catering students. Hence, the aim is to enable the researcher to make a comparison between the number of students who taken 'Basic Western' subjects with the use of Kahoot! in the learning process using game-based learning.

\section{REFERENCES}

[1] R. Dellos, "Kahoot! a digital game resource for learning," Int. J. Instr. Technol. Distance Learn., vol. 12, no. 4, pp. 49-52, 2015.

[2] F. Kirschner, F. Paas, P. A. Kirschner, and J. Janssen, "Differential effects of problem-solving demands on individual and collaborative learning outcomes," Learn. Instr., vol. 21, no. 4, pp. 587-599, Aug. 2011, doi: 10.1016/j.learninstruc.2011.01.001.

[3] K. M. Kapp, The Gamification of Learning and Instruction: Game-based Methods and Strategies for Training and Education. San Francisco: John Wiley \& Sons, 2012.

[4] L. P. Rieber, "Seriously considering play: Designing interactive learning environments based on the blending of microworlds, simulations, and games," Educ. Technol. Res. Dev., vol. 44, no. 2, pp. 43-58, 1996, doi: 10.1007/BF02300540.

[5] Z. Hussin, S. Siraj, G. Darusalam, and N. H. M. Salleh, "Kajian model blended learning dalam jurnal terpilih: satu analisa kandungan," JuKu J. Kurikulum Pengajaran Asia Pasifik, vol. 3, no. 1, pp. 1-6, 2017, [Online]. Available: https://juku.um.edu.my/article/view/814 2.

[6] W. C. Lin, J. Y. Ho, C. H. Lai, and B. S. Jong, "Mobile game- based learning to inspire students learning motivation," in In 2014 International Conference on Information Science, Electronics and Electrical Engineering (ISEEE), 2014, pp. 810-813, doi: 10.1109/infoseee.2014.6947779.

[7] S. Erhel and E. Jamet, "Digital gamebased learning: Impact of instructions 
and feedback on motivation and learning effectiveness," Comput. Educ., vol. 67, pp. 156-167, Sep. 2013, doi: 10.1016/j.compedu.2013.02.019.

[8] A. Mathrani, S. Christian, and A. Ponder-Sutton, "PlayIT: game based learning approach for teaching programming concepts," Educ. Technol. Soc., vol. 19, no. 2, pp. 5-17, 2016.

[9] G. J. Hwang, L. Y. Chiu, and C. H. Chen, "A contextual game-based learning approach to improving students' inquiry-based learning performance in social studies courses," Comput. Educ., vol. 81, pp. 13-25, Feb. 2015, doi: 10.1016/j.compedu.2014.09.006.

[10] A. R. Denham, R. Mayben, and T. Boman, "Integrating game-based learning initiative: increasing the usage of game-based learning within k-12 classrooms through professional learning groups," TechTrends, vol. 60, no. 1, pp. 70-76, Jan. 2016, doi: 10.1007/s11528-015-0019-y.

[11] T. Reiners and L. Wood, Gamification in Education and Business. Cham: Springer, 2015.

[12] S. A. Licorish, H. E. Owen, B. Daniel, and J. L. George, "Students' perception of Kahoot!'s influence on teaching and learning," Res. Pract. Technol. Enhanc. Learn., vol. 13, no. 1, p. 9, Dec. 2018, doi: 10.1186/s41039-018-0078-8.

[13] M. Mansur and D. Fadhilawati, "Applying Kahoot to improve the Senior High School students' vocabulary achievement," VELES Voices English Lang. Educ. Soc., vol. 3, no. 2, p. 164, Oct. 2019, doi: 10.29408/veles.v3i2.1591.

[14] F. Rofiyarti and A. Y. Sari, "TIK untuk AUD:penggunaan platform 'kahoot!' dalam menumbuhkan jiwa kompetitif dan kolaboratif anak," Pedagog. J. Anak Usia Dini dan Pendidik. Anak Usia Dini, vol. 3, no. 3b, pp. 164-172, 2017.

[15] D. Sandy, "Use of Kahoot as an evaluation and teaching learning tool in the teaching of industrial microbiology," Holos, vol. 1, pp. 170-179, 2018.
[16] D. S. Santos, "The quiz do bis: Use of Kahoot! as a learning tool," 2017.

[17] D. Tan, M. Ganapathy, and M. K. M. Singh, "Kahoot! it: gamification in higher education," Pertanika J. Soc. Sci. Humanit., vol. 26, no. 1, pp. 565-582, 2018.

[18] A. I. Wang and A. Lieberoth, "The effect of points and audio on concentration, engagement, enjoyment, learning, motivation, and classroom dynamics using Kahoot!," 2016.

[19] B. Taylor and E. Reynolds, "Building vocabulary skills and classroom engagement with Kahoot!," in 26th Korea TESOL international conference, 2018 , p. 89.

[20] H. Hadijah, B. W. Pratolo, and R. Rondiyah, "Interactive game 'Kahoot!' as the media of students' vocabulary assessment," J. English as a Foreign Lang., vol. 10, no. 1, pp. 87-105, Mar. 2020, doi: 10.23971/jefl.v10i1.1670.

[21] R. V. Krejcie and D. W. Morgan, "Determining sample size for research activities," Educ. Psychol. Meas., vol. 30, no. 3, pp. 607-610, Sep. 1970, doi: 10.1177/001316447003000308.

[22] S. Kocakoyun, "Perceptions of students for gamification approach: Kahoot as a case study," Int. J. Emerg. Technol. Learn., vol. 13, no. 02, pp. 72-93, Feb. 2018, doi: 10.3991/ijet.v13i02.7467.

[23] N. Yürük, "Edutainment: using Kahoot! as a review activity in foreign language classrooms," J. Educ. Technol. Online Learn., vol. 2, no. 2, pp. 89-101, 2019, doi: $10.31681 /$ jetol.557518.

[24] P. A. Baszuk and M. L. Heath, "Using Kahoot! to increase exam scores and engagement," J. Educ. Bus., vol. 95, no. 8, pp. 548-552, Nov. 2020, doi: 10.1080/08832323.2019.1707752.

[25] E. G. L. Medina and C. P. R. Hurtado, "Kahoot! a digital tool for learning vocabulary in a language classroom," Rev. Publicando, vol. 4, no. 12 (1), pp. 441-449, Sep.2017, Accessed: Mar. 17, 2021. [Online]. Available: https://revistapublicando.org/revista/inde x.php/crv/article/view/673. 